\title{
A STUDY OF THE INFLUENCE OF
}

\author{
BUSINESS STRATEGY ON
}

\section{OUTSOURCING HUMAN RESOURCES}

\section{FUNCTIONS OF THE MANUFACTURING}

\section{SECTOR IN SRI LANKA}

PREMA CHANDRA KUMARATHUNGAGE MAHIL ASANKA

MBA/MPM/MSc. in Management Program - 2009

University of Sri Jayewardenepura 
A STUDY OF THE INFLUENCE OF BUSINESS STRATEGY ON OUTSOURCING HUMAN RESOURCE FUNCTIONS OF THE MANUFACTURING SECTOR IN SRI LANKA

$$
\text { by }
$$

PREMA CHANDRA KUMARATHUNGAGE MAHIL ASANKA Reg No: 5266FM2009010 
A STUDY OF THE INFLUENCE OF BUSINESS STRATEGY ON OUTSOURCING HUMAN RESOURCE FUNCTIONS OF THE MANUFACTURING SECTOR IN SRI LANKA

$$
\text { by }
$$

PREMA CHANDRA KUMARATHUNGAGE MAHIL ASANKA Reg No: 5266FM2009010

A research report submitted to the University of Sri Jayewardenepura in partial fulfillment of the requirements of the Master of Business Administration on $5^{\text {th }}$ December 2011 


\section{Declaration}

"The work described in this research was carried out by me under the supervision of Dr. (Ms) Bhadra Arachchige and a report on this has not been submitted in whole or part to any University or any other institution for another Degree/Diploma".

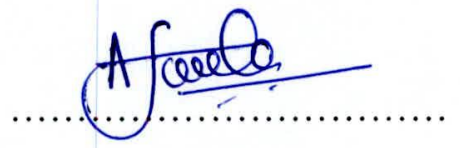

Date: $05 \cdot 12 \cdot 2011$

P.C.K.M.Asanka

(Reg. No: 5266FM2009010) 


\section{Supervisor's Recommendation}

I certify that this research; A study of the Influence of Business Strategy on Outsourcing

Human Resource Functions of the Manufacturing Sector in Sri Lanka, made by P.C.K.M.Asanka (Reg. No: 5266FM2009010) is true and that this research is suitable for submission to the University for the purpose of evaluation".

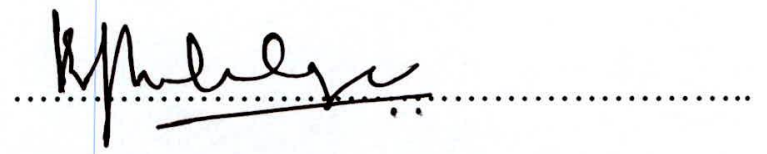

Date:..05 . 12: 20.1.1

Dr. (Ms) Bhadra Archchige

Senior Lecturer 


\section{ACKNOWLEDGEMENT}

I am infinitely grateful to my supervisor Dr. (Ms) Bhadra Arachchige, a Senior Lecturer supervising my thesis. I wish to express my sincere indebtedness to my supervisor for his supervision, encouragement, patience, and excellent support granted throughout this study to ensure the accuracy and completeness of my thesis. Further I honour for the guidance and assistance given to me by scarifying her valuable time and energy to make this thesis a success. I take this opportunity give my sincere gratitude to my other lecturers Dr. P.D. Nimal, Mr. Dias, Dr. D.T.W.S. Yapa who gave their maximum support irrespective.

I owe my gratitude to Managing Director, and immediate superiors at Royal Ceramics Lanka PLC who gave their maximum support and encourages and the respondents of other companies who scarified their valuable time to gather the data. Further, I would thanks to the editor Mrs. Janzs for giving her fullest support.

And last but not least, my heartfelt thank goes to my mother, my loving wife and sister, friends, and all the lectures of the University of Sri Jayewardenepura for their support, encouragements, and cooperation during my entire Master of Business Administration Degree programme.

P.C.K.M. Asanka

December, 2011 


\begin{abstract}
ABSRTACT
In the process of enhancing the wealth of the shareholders, in the last few decades, business organizations have tried to achieve their objectives by using many strategic decisions and doing those through different managerial techniques; TQM and Business Process Reengineering (BPR), Rightsizing, Downsizing, Restructuring and Business Process Outsourcing (BPO). Outsourcing HR activities fell under this BPO. This research study examines whether outsourcing human resources functions have any relationship with the business strategy that consists of basically quality-based strategy, proactive strategy, breadth strategy and reactive strategy. Further it explained how business strategy jointly and collectively influences outsourcing HR activity and which business strategy has the most influence on transactional and traditional HR activity in the manufacturing sector in Sri Lanka. With the intention to answer the above this study selected the manufacturing companies in Sri Lanka. The selected sample is public quoted companies in the Colombo Stock Exchange. It consists of thirty four manufacturing companies and all are selected for the sample. A survey was conducted to collect primary data with a structured questionnaire.
\end{abstract}

According to the findings the payroll activity, training, recruitment and selection activities have been outsourced by these manufacturing companies in Sri Lanka. The most outsourced activity was payroll. The hypothesis tested on this study shows that quality based strategy has a relationship with neither transactional nor traditional HR activities outsourcing. Statically there is a positive relationship between proactive business strategy and transactional HR activities. However, the relationship with the outsourcing of traditional HR activity, only outsourcing of training has a positive relationship. In the breadth strategy and the reactive strategy, also has no relationship with both business strategies and transactional and traditional HR activities. Among all business strategies, the proactive business strategy is the most influential business strategy in outsourcing of HR activities especially on Payroll HR activities. Overall the transactional HR activity is the most influenced HR activity from business strategies. 


\section{TABLE OF CONTENTS}

Content

Page

Title page

$i$

Declaration

ii

Recommendation of the Supervisor iii

Acknowledgement iv

Abstract v v

Table of Contents vi vi

List of Tables $x$

List of Figures $\quad x i i$

List of Abbreviation xiii

$1 \quad$ INTRODUCTION

\begin{tabular}{l|r}
1.1 & Introduction to the study
\end{tabular}

1.2 Statement of Problem 4

\begin{tabular}{l|r}
1.3 & Problem Justification
\end{tabular}

\begin{tabular}{l|l}
1.4 & Significance of the Study
\end{tabular}

$\begin{array}{llr}1.5 & \text { Objectives of the study } & 8\end{array}$

\begin{tabular}{l|r}
1.6 & Scope of the study
\end{tabular}

1.7 Organization of the Research $\quad 8$ 
2. LITERATURE REVIEW 10-43

$\begin{array}{lll}2.1 & \text { Introduction } & 10\end{array}$

$\begin{array}{lll}2.2 & \text { Outsourcing } & 10\end{array}$

2.3 Outsourcing Human Resource Functions 27

\begin{tabular}{l|l}
2.4 & Business Strategy
\end{tabular}

2.5 Influence of Business Strategy on HR Outsourcing 42

$\begin{array}{lll}2.6 & \text { Summary } & 43\end{array}$

3 CONCEPTUALIZATION AND OPERATIONALIZATION

$\begin{array}{lll}3.1 & \text { Introduction } & 44\end{array}$

3.2 Conceptualization of Reseach Problem 44

$\begin{array}{lll}3.3 & \text { Conceptual Model } & 49\end{array}$

\begin{tabular}{l|r}
3.4 & List of Hypotheses \\
\end{tabular}

3.5 Definition of key Concepts 51

3.6 Operationalization Variables 53

$\begin{array}{lll}3.7 & \text { Summary } & 57\end{array}$

4. RESEARCH METHODOLOGY 58-64

$\begin{array}{llr}4.1 & \text { Introduction } & 58\end{array}$

$\begin{array}{llr}4.2 & \text { Survey } & 58\end{array}$

4.3 Method of Data Collection $\quad 59$

\begin{tabular}{l|l}
4.4 & Population and Sampling
\end{tabular}

$\begin{array}{lll}4.5 & \text { Respondents } & 62\end{array}$ 
4.6 Administration of the Survey 62

$\begin{array}{lll}\text { 4.7 Data Analysis Techniques } & 63\end{array}$

$\begin{array}{lll}4.8 & \text { Reliability and Validity of the Research } & 63\end{array}$

$\begin{array}{lll}4.9 & \text { Pilot Test } & 64\end{array}$

$\begin{array}{lll}4.10 & \text { Summary } & 64\end{array}$

5. ANALYSIS OF DATA

$\begin{array}{lll}5.1 & \text { Introduction } & 65\end{array}$

$\begin{array}{lll}5.2 & \text { Sample Distribution } & 65\end{array}$

$\begin{array}{lll}5.3 & \text { Reliability and Validity of the measurement }\end{array}$

$\begin{array}{lll}5.4 & \text { Justification of Factor Loading } & 72\end{array}$

5.5 Descriptive Statistics and Data presentation of Business Strategy

$\begin{array}{ll}\text { \& HR Activities } & 72\end{array}$

$\begin{array}{ll}\text { 5.6 Analysis of Structural Model } & 80\end{array}$

$\begin{array}{ll}\text { 5.6.1. Testing Hypotheses } & 81\end{array}$

5.7 Influence of Business Strategy on Outsourcing HR Functions 87

$\begin{array}{lll}5.8 & \text { Summary } & 92\end{array}$

6. DISCUSSION AND FINDINGS $\quad \mathbf{9 4 - 1 0 4}$

$\begin{array}{lll}6.1 & \text { Introduction } & 94\end{array}$

6.2 The Outsourced HR Activities 94

6.3 Influence of Business Strategies on outsourcing HR activity 97

$\begin{array}{ll}\text { 6.3.1 Discussion with Correlation } & 97\end{array}$ 
$\begin{array}{lll}\text { 6.3.2 Discussion with Multiple regressions } & 102\end{array}$

6.4 Summary

104

7 CONCLUSION

105-107

$\begin{array}{llr}7.1 & \text { Conclusion } & 105\end{array}$

$\begin{array}{lll}7.2 & \text { Limitation of the Study } & 107\end{array}$

\section{Reference}

Appendix I - $\quad$ Research Questionnaire

Appendix II - Sample List

Appendix III - $\quad$ Statistical Analysis - Regression 


\section{LIST OF TABLES}

Table No.

Description

Page No.

2.1

Definition of Outsourcing

Expected benefits sought from Outsourcing

Potential risk of outsourcing

$3.1 \quad$ Operationaliazation of Variables 54

$\begin{array}{lll}5.1 & \text { Sample Distribution } & 66\end{array}$

$\begin{array}{lll}5.2 & \text { Reliability of Business Strategies } & 68\end{array}$

5.3 Exploratory Factor Analysis of Integrated Business Strategy $\quad 70$

$\begin{array}{lll}5.4 & \text { Descriptive Statistics of Business Strategies } & 73\end{array}$

$\begin{array}{lll}5.5 & \text { Descriptive Statistics of HR Activities }\end{array}$

5.6 Correlation - Quality-Based Business Strategy and

Transactional HR Activities $\quad 83$

5.7 Correlation - Quality-Based Business Strategy and

Traditional HR Activities

5.8 Correlation - Proactive Strategy and Transactional \& Traditional HR Activity

5.9 Correlation Coefficient - Breadth Strategy and Transactional

\& Traditional HR activity

5.10 Correlation Coefficient - Reactive Strategy and Transactional

\& Traditional Activity Analysis of Variance - Business Strategies and each HR Activity 88 


\section{LIST OF FIGURES}

Figures No.

Description

2.1 Outsourcing different types of Training

3.1 Conceptual Model

5.1 Graphical Presentation of Payroll Activity

5.2 Graphical Presentation of Benefit Activity

5.3 Graphical Presentation of Training Activity

5.4 Graphical presentation of recruitment activity

5.5 Graphical Presentation of Selection
Page No.

37

49

75

77

77

78

79 


\section{LIST OF ABBREVIATIONS}

BPO

HR

HRM

HRO

Business Process Outsourcing

Human Resources

Human Resources Management

Human Resources Outsourcing 